\title{
ANALISIS TINGKAT KETAATAN PENGEMUDI DAN PENUMPANG KENDARAAN PRIBADI DAN UMUM TERHADAP PENGGUNAAN SABUK KESELAMATAN
}

\author{
Nevin Nathanael. ${ }^{1}$, dan Leksmono Suryo Putranto ${ }^{2}$ \\ ${ }^{\text {I}}$ Program Studi Sarjana Teknik Sipil, Universitas Tarumanagara, Jl.Letjen S. Parman No.1 Jakarta \\ Email: Nevinnathanael1311@gmail.com \\ ${ }^{2}$ Program Studi Sarjana Teknik Sipil, Universitas Tarumanagara, Jl.Letjen S. Parman No. 1 Jakarta \\ Email:Lexy_putranto@yahoo.co.id
}

\begin{abstract}
ABSTRAK
Manusia, kendaraan dan lingkungan adalah tiga elemen utama dari moda jalan raya. Kebutuhan keselamatan berlalu lintas di jalan raya dipengaruhi oleh faktor perangkat yang memadai seperti sabuk keselamatan dalam kendaraan. Survei tingkat ketaatan pengguna kendaraan bermotor pribadi maupun umum terhadap pengunaan sabuk keselamatan dilakukan di 7 titik lokasi di Jakarta Timur. Survei lapangan ini dilakukan guna memvalidasi hasil survei yang telah dilakukan pada tahun 2004. Penyebaran kuesioner kepada 50 responden yang terbagi menjadi dua bagian. Bagian pertama berisi tentang data umum responden seperti nama, jenis kelamin, umur, pendidikan terakhir, kepemilikan SIM dan pengeluaran per bulan. Bagian kedua adalah pertanyaan untuk menilai tingkat ketaatan pengemudi dan penumpang terhadap penggunaan sabuk keselamatan. 25 responden diminta mengisi kuesioner secara langsung dan 25 responden lainnya mengisi kuesioner daring. Analisis data menggunakan analisis selisih rataan untuk mengobservasi kemungkinan hubungan antara tingkat ketaatan penggunaan sabuk keselamatan dengan perbedaan jenis kelamin, umur, kepemilikan SIM, pendidikan terakhir dan pengeluaran per bulan. Berdasarkan hasil analisis, terdapat peningkatan persentase penggunaan sabuk keselamatan secara signifikan pada 4 lokasi survei tetapi terdapat juga penurunan persentase penggunaan sabuk keselamatan secara signifikan di 3 loksai survey lainya. Sedangkan hasil analisis kuesioner didapat bahwa responden menggunakan sabuk keselamatan berdasarkan pengaruh dari keberadaan petugas, lokasi perjalanan dan waktu perjalanan. Pengaruh dari keberadaan petugas dikonfirmasi dengan hasil survei pada Jl. Halim Perdanakusuma yang pada saat pengambilan data terdapat banyak petugas .
\end{abstract}

Kata kunci: tingkat ketaatanpenggunaan sabuk keselamatan, Sabuk Keselamatan, keselamatan berkenda

\section{PENDAHULUAN}

\section{Latar Belakang}

Selama ini diketahui bahwa ada tiga elemen utama dari moda jalan raya yaitu manusia, kendaraan dan lingkungan (Haddon, 1980; bab 16). Dimana ketiga elemen itu dimasukan kedalam kerangka kerja keamanan jalan raya. Dalam suatu kendaraan harus memiliki perangkat yang memadai seperti sabuk keselamatan (safety belt).

Pemerintah dan DPR sebagai pihak yang berwenang perlu membuat ketentuan-ketentuan dalam hal ini adalah Undang-undang. Pengaturan tersebut antara lain diatur dalam Undang-Undang Republik Indonesia No. 22 tahun 2009 tentang Lalu-lintas dan Angkutan Jalan. Salah satu dari pasal UU No.22 tahun 2009 adalah mengenai keselamatan, keamanan, kelancaran, dan ketertiban lalu lintas yang didalamnya ada suatu pasal yang mengatur tentang penggunaan sabuk keselamatan.

Pada tanggal 5 November 2003, Dirjen Perhubungan Darat menetapkan bahwa setiap pengendara dan penumpang di samping pengemudi kendaraan roda empat diharuskan memakai sabuk keselamatan dan pada 10 febuari 2018 telah mulai diberlakukan peraturan Mentri Perhubungan Nomor PM. 28 tahun 2015 dan peraturan Mentri Perhubungan Nomor PM 98 tahun 2013 tentang standar pelayanan minimal angkutan orang dengan kendaraan bermotor umum tidak dalam trayek maupun daklam trayek.

Segi positif dari diberlakukan aturan tentang penggunaan sabuk keselamatan adalah tumbuhnya kesadaran bagi para pengguna dan penumpang kendaraan agar menjaga keselamatan dan mengurangi angka kematian dari kecelakaan lalu lintas. 
Masalahnya adalah bagaimana masyarakat menjalankan terhadap peraturan dari pasal UU No. 22 tahun 2009 , dan sejauh mana masyarakat mengerti tentang peraturan tersebut. Sehingga untuk menjawab pertanyaan tersebut di lakukan penelitian dan survey yang akan di bandingkan dengan penelitian sebelumnya (Khusaini, 2004).

\section{Batasan Masalah}

Untuk meneliti seluruh masalah di atas memerlukan suatu survey kembali di lokasi yang sama, yaitu :

1. Jl. Otto Iskandardinata (6 lajur/ 2 arah bermedian), di depan hotel Fiducia.

2. Jl. Halim Perdana Kusuma (4 lajur / 2 arah bermedian), di dekat simpang susun Cawang.

3. Jl. Cawang Baru (2 lajur / 2 arah) di antara Jl. Cawang Barat dan Jl. Bineka.

4. Jl. Pinang Ranti

5. Jl. Raya Bogor (4 lajur / 2 arah bermedian), di depan pasar Kramat Jati.

6. Jl. Raya Condet (2 lajur / 2 arah)

7. Jl. Pinang Ranti, di dekat SMA 48.

Pengamatan dilaksanakan pada perkiraan jam puncak pagi hari (pukul 7.00-9.00)

Klasifikasi kendaraan yang diamati adalah sebagai berikut :

1. Mobil pribadi (sedan/jeep/van).

2. Taksi.

3. Angkutan kota.

4. Pick-up/Box

5. Bus umum

6. Bus non-umum

7. Truk

Pertanyan di berikan berupa kuisioner ke beragam jenis masyarakat yang rutin menggunakan kendaraan bermotor roda empat atau lebih.

\section{Rumusan Masalah}

Berdasarkan penelitian sebelumnya (Khusaini, 2004), menyatakan bahwa penggunaan safety belt pada penumpang kendaraan memiliki presentase rata-rata tidak lebih dari $75 \%$. Hal ini dipengaruhi karena penetapan peraturan yang baru berjalan beberapa saat pada tahun 2004. Seiring berjalan waktu dan himbauan selama 14 tahun, maka pengemudi maupun penumpang akan memiliki sifat sadar menggunakan safety belt saat berkendara. Pada skripsi ini akan di lakukan survey kembali di lokasi sama untuk membandingkan jumlah presentase penggunaan safety belt pada tahun 2004 dengan tahun 2018 dan akan melakukan survey ketaatan pengguna safety belt ke masyarakat umum.

\section{Tujuan Penelitian}

Penelitian / survey ini bertujuan untuk mengetahui tingkat ketaatan pengguna kendaraan bermotor pribadi atau umum terhadap penggunaan sabuk keselamatan dan memvalidasi kembali hasil survey penggunaan sabuk keselamatan pada tahun 2004.

\section{TINJAUAN PUSTAKA}

\section{Jenis-Jenis Sabuk keselamatan}

a. Jenis Pangkuan

Sabuk keselamatan jenis ini dapat disesuaikan yang melintang di atas pangkuan. Sabuk ini sering digunakan pada mobil-mobil tua, sekarang sudah jarang digunakan kecuali untuk penumpang yang duduk di tengah pada barisan belakang. Kursikursi penumpang pesawat terbang juga menggunakan sabuk kselamatan pangkuan. 


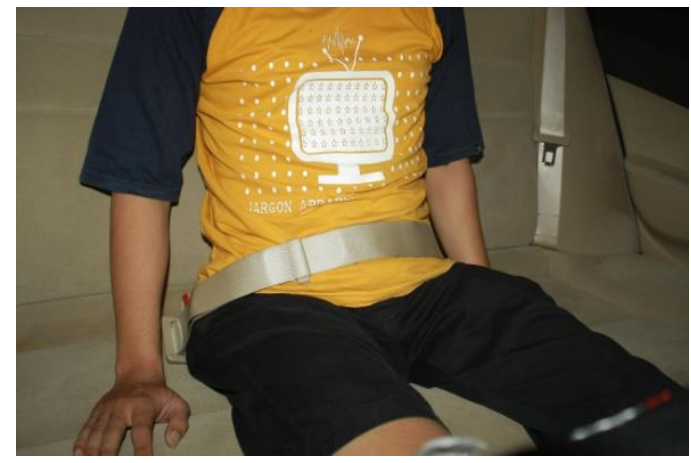

Gambar 1. Sabuk Keselamatan Jenis Pangkuan

\section{b. Dua titik (Two Points)}

Jenis sabuk keselamatan jenis ini sesuai dengan persyaratan teknis Keputusan Menteri Perhubungan Nomor Km. 37 tahun 2002 pasal 5. Sabuk Keselamatan sabuk keselamatan ini menggunakan sistem penahan dengan dua titik, terdiri dari pangkuan atau sabuk diagonal yang sudah jarang digunakan. Sabuk seperti ini biasanya digunakan pada mobil-mobil mewah yang lebih tua seperti Ford dari awal tahun 1990-an. Sabuk keselamatan jenis ini terbagi menjadi dua, yaitu :

- Sash, sabuk keselamatan jenis ini dapat disesuaikan yang melintang melewati

bahu. Biasa digunakan terutama pada tahun 1960-an, tetapi kegunaannya terbatas karena sangat mudah terlepas bila terjadi tabrakan;

- Pangkuan dan Sash, kombinasi dari dua jenis sabuk di atas (dua sabuk terpisah).

Terutama digunakan pada 1960-an dan 1970-an, biasanya di kursi belakang. Dan pada umumnya telah digantikan oleh desain tiga titik.

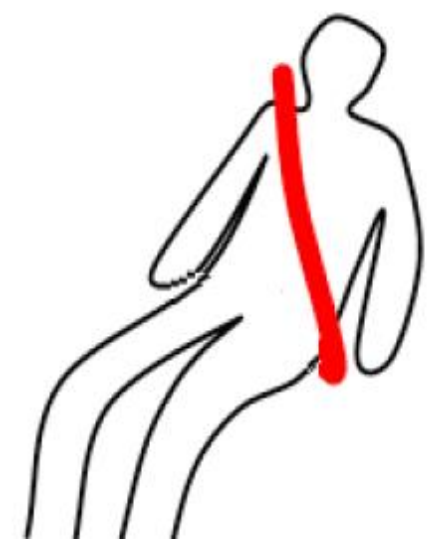

Gambar 2. Sabuk Keselamatan Dua Titik

\section{c. Tiga titik (Three Points)}

Jenis sabuk keselamatan jenis ini sesuai dengan persyaratan teknis Keputusan Menteri Perhubungan Nomor Km. 37 tahun 2002 pasal 5. Sabuk keselamatan ini menggunakan sistem penahan dengan tiga titik. Jenis ini serupa dengan pangkuan dan sash, tetapi membentuk satu jaringan yang sinambung. Baik sabuk pengaman tiga titik maupun jenis pangkuan dan sash menolong menyebarkan energi dari tubuh yang bergerak dalam sebuah tabrakan ke dada, selangkangan dan bahu. Hingga tahun 1980-an sabuk tiga titik umumnya terdapat di kursi depan saja, sedangkan di kursi belakang hanya tersedia sabuk pangkuan. Bukti-bukti bahwa sabuk pangkuan berpotensi menyebabkan terpisahnya lumbar vertebrae dan kadang-kadang kelumpuhan yang Penuntun Gelincir (Slip Guide) terkait, atau 
"sindroma sabuk keselamatan", telah menyebabkan direvisinya aturanaturan keamanan pada hampir semua negara maju yang mengharuskan agar semua bangku di dalam kendaraan dilengkapi dengan sabuk tiga titik. Negara Amerika Serikat mulai memberlakukan peraturan bagi semua mobil baru yang dijual, sudah harus dilengkapi dengan sabuk keselamatan bahu dan pangkuan untuk penumpang di kursi belakang serta kursi ditengah pada 1 September 2007.

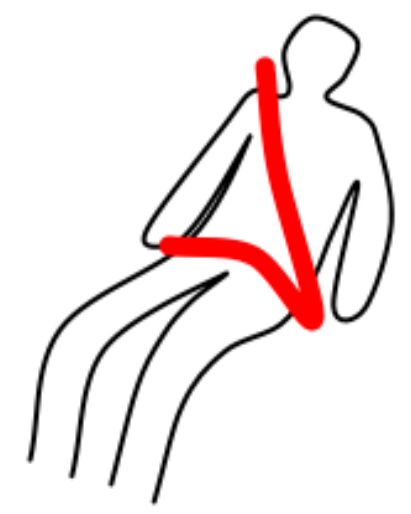

Gambar 3. Sabuk Keselamatan Tiga Titik

\section{d. Empat titik (Four Points)}

Jenis sabuk keselamatan jenis ini sesuai dengan persyaratan teknis Keputusan Menteri Perhubungan Nomor Km. 37 tahun 2002 pasal 5. Sabuk keselamatan ini menggunakan sistem penahan dengan empat titik. Sistem ini sudah canggih dan sangat efektif mengurangi bahaya kematian bila terjadi tabrakan.

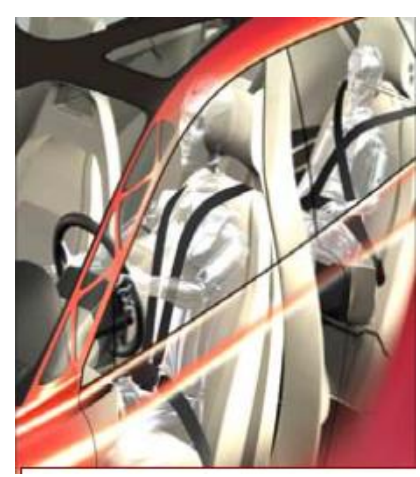

Gambar 4. Sabuk Keselamatan Empat Titik

e. Enam titik (Six Points)

Jenis sabuk keselamatan ini digunakan pada fitur keselamatan mobil balap F1. Dengan sistem sabuk pengaman 6 titik ini, kedua bahu, pangkal paha dan perut pembalap dapat ditahan dengan baik. Untuk memasangnya, pembalap perlu dibantu tim mekanik, sedangkan untuk melepas cukup menekan satu tombol penguncinya.

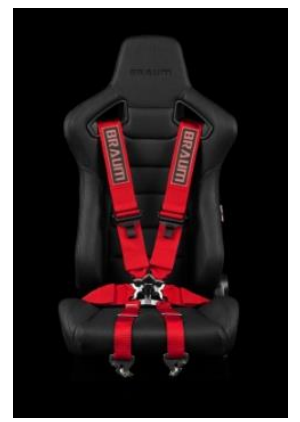

Gambar 2.11 Sabuk Keselamatan Enam Titik 


\section{Penerapan Hukum Pengunaan Sabuk Keselamatan di Indonesia}

Penelitian yang dilakukan di Indonesia pada tahun 2005, berdasarkan wawancara terhadap 50 responden pengemudi/penumpang mobil pribadi yang dipilih secara acak berdasarkan buku telepon di 5 wilayah di Jakarta, mendapatkan bahwa $78 \%$ responden di Jakarta selalu menggunakaan sabuk keselamatan, sedangkan $22 \%$ responden menyatakan sering atau kadang-kadang menggunakan. 64\% diantara responden yang tidak menggunakan sabuk keselamatan mengatakan bahwa sikap ini dipengaruhi oleh lokasi jalan yang dilalui, 27\% dipengaruhi oleh kapan perjalanan tersebut dilakukan dan 9\% sisanya dipengaruhi oleh sebab-sebab lain (Putranto, 2005).

Intervensi untuk meningkatkan pemakaian sabuk keselamatan dilakukan berbagai cara salah satunya adalah penerapan hukum dan praktek perundang-undangan. untuk mengganti UU No.14 tahun 1992 tentang Lalu- Lintas dan Angkutan Jalan Raya, karena tidak sesuai lagi dengan perkembangan zaman, kemajuan ilmu pengetahuan dan teknologi, dan belum tertata dalam satu kesatuan sistem yang merupakan bagian dari transportasi secara keseluruhan. Maka pemerintah Indonesia menerapkan sistem Undang-undang yang baru yaitu UU No.22 tahun 2009 tentang Lalu- Lintas dan Angkutan Jalan Raya. Salah satu pasalnya mengatur tentang tata cara berlalu lintas yang di dalamnya terdapat pasal yang mengatur tentang penggunaan sabuk keselamatan, yaitu ;

1. UU No.22 tahun 2009 pasal 106 ayat (6) yang berbunyi : Setiap orang yang mengemudikan Kendaraan Bermotor beroda empat atau lebih di Jalan dan penumpang yang duduk di sampingnya wajib mengenakan sabuk keselamatan.

2. UU No.22 tahun 2009 pasal 106 ayat (7) yang berbunyi :

3. Setiap orang yang mengemudikan Kendaraan Bermotor beroda empat atau lebih yang tidak dilengkapi dengan rumah-rumah di Jalan dan penumpang yang duduk di sampingnya wajib mengenakan sabuk keselamatan dan mengenakan helm yang memenuhi standar nasional Indonesia.

4. UU No.22 tahun 2009 pasal 289 yang berbunyi :

5. Setiap orang yang mengemudikan Kendaraan Bermotor atau Penumpang yang duduk di samping Pengemudi yang tidak mengenakan sabuk keselamatan sebagaimana dimaksud dalam Pasal 106 ayat (6) dipidana dengan pidana kurungan paling lama 1 (satu) bulan atau denda paling banyak Rp250.000,00 (dua ratus lima puluh ribu rupiah).

6. UU No.22 tahun 2009 pasal 290 yang berbunyi :

7. Setiap orang yang mengemudikan dan menumpang Kendaraan Bermotor selain Sepeda Motor yang tidak dilengkapi dengan rumah-rumah dan tidak mengenakan sabuk keselamatan dan mengenakan helm sebagaimana dimaksud dalam Pasal 106 ayat (7) dipidana dengan pidana kurungan paling lama 1(satu) bulan atau denda paling banyak Rp250.000,00 (dua ratus lima puluh ribu rupiah).

\section{METODOLOGI PENELITIAN}

\section{Prosedur Penelitian Survey Lapangan}

Penlitian akan dilakukan secara 2 metode yaitu survey lapangan dan kuesioner. Survey lapangan akan dilakukan di 7 tempat yang telah di lakukan survey sebelumnya pada tahun 2004 yaitu :

1. Jl. Otto Iskandardinata (6 lajur $/ 2$ arah bermedian), di depan hotel Fudicia.

2. J1. Halim Perdanakusuma (4 lajur $/ 2$ arah bermedian), di dekat simpang susun Cawang.

3. Jl. Cawang Baru (2 lajur/2 arah ) di antara Jl. Cawang Baru dan Jl. Bhineka.

4. Jl. Raya Taman Mini ( 6 lajur/2 arah bermedian), di depan Masjid At-Tien.

5. Jl. Raya Bogor (4 lajur / 2 arah bermedian ), di depan pasar Kramat Jati.

6. Jl. Raya Condet ( 2 lajur / 2 arah), di depan Masjid Asholihin.

7. J1. Pinang Ranti, di dekat SMA 48.

Survey lapangan dilakukan pada saat jam puncak pagi hari (pukul 07.00 -09.00) pada hari senin hingga jumat. Survey dilakukan selama 15 menit di masing-masing lokasi. Pengamatan dilakukan di satu lajur terpadat di masingmasing jalan yang sudah di tentukan.

Pengamatan dilakukan dari tempat yang mudah dan aman seperti di atas trotoar atau jembatan penyebrangan untuk dilakukan pengamatan.Proses pengamatan menggunakan kamera video yang digunakan untuk merekam aktifitas kendaraan. Pengolahan data akan dilakukan dengan cara melihat hasil rekaman dan mencatat di formulir yang sudah disiapkan.

\section{Prosedur Penelitian Kuesioner}

Data dikumpulkan dari 50 Responden masyarakat dengan berbagai latar belakang yang berbeda-beda. Semua Responden adalah masyarakat yang setiap hari mengendarai mobil pribadi atau kendaraan roda empat lainya. 
Dalam penelitian ini digunakan dua metode kuesioner yakni daring dan langsung. Kuesioner langsung dibagikan kepada 25 responden. Responden dapat langsung bertanya kepada penyurvei apabila ada butir pertanyaan yang kurang jelas. Sebanyak 25 kuesioner dibagikan secara daring meng-gunakan Google Form. Tautan untuk mengisi kuesioner tersebut dibagikan melalui email atau aplikasi seperti Whatsapp dan Line.

Kuesioner bersisi 2 bagian utama yakni data umum dan butir pertanyaan. Pada data umum responden diminta untuk mengisi nama, jenis kelamin, umur, domisili sekarang, pengeluaran perbulan, Pendidikan yang sudah ditempuh. Pada bagian kedua dalam penelitian ini terdapat 17 butir pertanyaan dan ada 5 indikator yang akan diuji. Responden diminta untuk mengisi kuesioner mengenai tingkat ketaatan penggunaan sabuk keselamatan menggunakan Skala Likert dimana nilai 1 menunjukkan sangat tidak taat hingga nilai 4 menunjukkan sangat taat. Berikut adalah pertanyaan-pertanyaan yang terdapat dalam kuesioner:

1. Saya merasa safety belt three points yang sekarang banyak digunakan pada kendaraan penumpang dapat melindungi saya ketika berkendara.

2. Saya merasa safety belt three points yang sekarang banyak digunakan pada kendaraan penumpang sudah terasa nyaman

3. Saya merasa safety belt three points yang sekarang banyak digunakan pada kendaraan penumpang harus di tingkatkan kenyamananya

4. Saya merasa safety belt three points yang sekarang banyak digunakan pada kendaraan penumpang harus di tingkatkan fungsi keselamatanya

5. Saya merasa penumpang selain pengemudi kendaraan mobil harus menggunakan safety belt

6. Saya merasa penumpang kendaraan umum seperti bis atau angkutan kota harus menggunakan safety belt

7. Saya merasa penumpang kendaraan truk atau kendaraan berat lain nya yang duduk di samping pengemudi harus menggunakan safety belt

8. Ketaatan saya menggunakan safety belt dipengaruhi keberadaan petugas

9. Ketaatan saya menggunakan safety belt dipengaruhi waktu perjalanan seperti pagi, siang, atau malam

10. Ketaatan saya menggunakan safety belt dipengaruhi lokasi perjalanan

11. Saya selalu menggunkan safety belt ketika berkendara

12. Saya selalu menggunakan safety belt ketika menjadi penumpang yang duduk di depan

13. Saya selalu menggunkana safety belt ketika menjadi penumpang yang duduk di belakang

14. Saya selalu menggunakan safety belt sesuai dengan aturan

15. saya selalu memerika kondisi safety belt sebelum berkendara

16. Saya selalu merawat safety belt kendaraan

17. Saya selalu membersihkan safety belt kendaraan

Indikator pertanyaan pada pertanyaan nomor 1 hingga 4 adalah Rancangan Sabuk Keselamatan. Indikator pertanyaan pada pertanyaan nomor 5 hingga 7 adalah Kewajiban penggunaan sabuk keselamatan pada penumpang. Indikator pertanyaan pada pertanyaan nomor 8 hingga 10 adalah ketaatan penggunaan sabuk keselamatan dari faktor eksternal. Indikator pertanyaan pada pertanyaan nomor 11 hingga 14 adalah ketaatan penggunaan sabuk keselamatan dari faktor internal. Indikator pertanyaan pada pertanyaan nomor 15 hingga 17 adalah perawatan sabuk keselamatan.

\section{Data Penelitian}

Terdapat 50 responden yang berpartisipasi dalam penelitian ini. Tabel 1 menunjukkan distribusi data berdasarkan jenis kelamin dan tipe kuesioner..

Tabel 2. Distribusi Responden Berdasarkan Jenis Kelamin dan Tipe Kuesioner

\begin{tabular}{|c|c|c|}
\hline \multirow{2}{*}{} & \multicolumn{2}{|c|}{ Jumlah Responden } \\
\cline { 2 - 3 } & Rencana & Realisasi \\
\hline Laki-laki & 25 & 33 \\
\hline Perempuan & 25 & 17 \\
\hline Total & 50 & 50 \\
& & \\
\hline
\end{tabular}


Dari Skala Likert kita mendapatkan penilaian tingkat kepuasan dengan hasil bervariasi diantara 1 hingga 4. Angka 2,5 merupakan batas penilaian antara taat dan tidak taat terhadap penggunaan sabuk keselamatan. Berikut adalah tingkat ketaatan per indikator pertanyaan:

1. 3,29: Indikator rancangan Sabuk Keselamatan.

2. 3,15: Indikator kewajiban penggunaan sabuk keselamatan pada penumpang.

3. 2,61: Indikator ketaatan penggunaan sabuk keselamatan dari faktor eksternal.

4. 3,05: Indikator ketaatan penggunaan sabuk keselamatan dari faktor internal.

5. 1,89: Indikator perawatan sabuk keselamatan

\section{ANALISIS DAN PEMBAHASAN}

Pada Hasil survey lapangan dapat dilihat bahwa terjadi peningkatan di 4 lokasi survey dan ada penurunan di 3 lokasi survey. Pada Jl. Halim Perdanakusuma mengalami peningkatan persentase penggunaan sabuk keselamatan mendekati $100 \%$. Saat pengambilan data di Jl. Halim perdanakusuma terdapat banyak petugas yang sedang berjaga, ini membuat persentase tingkat penggunaan sabuk keselamatan meningkat. Ini sesuai dengan hasil kuesioner yang mengatakan bahwa rata-rata responden taat menggunaan sabuk keselamatan dipengaruhi oleh keberadaan petugas.

Tabel 3. Uji Selisih Rataan Untuk Survey Lapangan Terhadap Pengemudi di Jl. Halim Perdanakusuma

\begin{tabular}{|c|c|c|r|r|r|r|r|}
\hline $\begin{array}{c}\text { Jenis } \\
\text { Kendaraan }\end{array}$ & $\begin{array}{c}\text { Jumlah } \\
\text { Pengemudi } \\
\mathbf{2 0 0 4}\end{array}$ & $\begin{array}{c}\text { Jumlah } \\
\text { Pengemudi } \\
\mathbf{2 0 1 8}\end{array}$ & $\begin{array}{c}\mathbf{2 0 0 4} \\
\mathbf{( \% )}\end{array}$ & $\begin{array}{c}\mathbf{2 0 1 8} \\
\mathbf{( \% )}\end{array}$ & $\begin{array}{c}\text { Selisih } \\
\text { Rataan } \\
(\boldsymbol{\%})\end{array}$ & $\begin{array}{c}\text { Tingkat } \\
\text { Signifikan }\end{array}$ & $\begin{array}{c}\text { Signifikan? } \\
\text { (YA/TIDAK) }\end{array}$ \\
\hline $\begin{array}{c}\text { Kendaraan } \\
\text { Pribadi }\end{array}$ & 912 & 208 & 87,1 & 91,8 & 4,7 & 0,013 & YA \\
\hline Taksi & 132 & 38 & 85,7 & 66,0 & $-19,8$ & $<0,001$ & YA \\
\hline $\begin{array}{c}\text { Angkutan } \\
\text { Kota }\end{array}$ & 6 & - & 0 & 0 & - & - & TIDAK \\
\hline $\begin{array}{c}\text { Pick- } \\
\text { up/Box }\end{array}$ & 65 & 2 & 89,8 & 100 & 10,1 & 0,027 & YA \\
\hline Truk & 38 & 6 & 88,0 & 50,0 & -38 & $<0,001$ & YA \\
\hline
\end{tabular}

Tabel 4. Uji Selisih Rataan Untuk Survey Lapangan Terhadap Penumpang di Jl. Halim Perdanakusuma

\begin{tabular}{|c|c|c|r|r|r|r|r|}
\hline $\begin{array}{c}\text { Jenis } \\
\text { Kendaraan }\end{array}$ & $\begin{array}{c}\text { Jumlah } \\
\text { Penumpang } \\
\mathbf{2 0 0 4}\end{array}$ & $\begin{array}{c}\text { Jumlah } \\
\text { Penumpang } \\
\mathbf{2 0 1 8}\end{array}$ & $\begin{array}{c}\mathbf{2 0 0 4} \\
\mathbf{( \% )}\end{array}$ & $\begin{array}{c}\mathbf{2 0 1 8} \\
\mathbf{( \% )}\end{array}$ & $\begin{array}{c}\text { Selisih } \\
\text { Rataan } \\
\mathbf{( \% )}\end{array}$ & $\begin{array}{c}\text { Tingkat } \\
\text { Signifikan }\end{array}$ & $\begin{array}{c}\text { Signifikan? } \\
(\text { YA/TIDAK) }\end{array}$ \\
\hline $\begin{array}{c}\text { Kendaraan } \\
\text { Pribadi }\end{array}$ & 330 & 111 & 74,9 & 91,9 & 17,1 & $<0,001$ & YA \\
\hline Taksi & 12 & 13 & 37,6 & 85,0 & 47,4 & 0,036 & YA \\
\hline $\begin{array}{c}\text { Angkutan } \\
\text { Kota }\end{array}$ & 6 & 0 & 0 & 0 & 0 & - & TIDAK \\
\hline $\begin{array}{c}\text { Pick- } \\
\text { up/Box }\end{array}$ & 40 & 2 & 58,3 & 100 & 41,7 & 0,006 & YA \\
\hline Truk & 32 & 3 & 56,8 & 66,7 & 9,9 & 0,527 & TIDAK \\
\hline
\end{tabular}

Berdasarkan hasil dari kuesioner kita dapat melihat bahwa pada indikator "Saya merasa safety belt three points yang sekarang banyak digunakan pada kendaraan penumpang dapat melindungi saya ketika berkendara" dan "Saya merasa safety belt three points yang sekarang banyak digunakan pada kendaraan penumpang sudang terasa nyaman" memiliki rataan yang tinggi. Ini menunjukan bahwa semua responden merasa bahwa rancangan pada sabuk keselamatan sudah membuat responden terasa terlindungi dan nyaman. Tetapi pada indikator "Saya merasa safety belt three points yang sekarang banyak digunakan pada kendaraan penumpang harus ditingkatkan kenyamananya" dan "Saya merasa safety belt three points yang sekarang banyak digunakan pada kendaraan penumpang harus 
ditingkatkan fungsi keselamatanya" memiliki nilai rataan yang tinggi juga, ini menunjukan bahwa responden juga mengharpkan peningkatan fungsi keselamatan dan kenyamanan dari sabuk keselamatan.

pada indikator kewajiban penggunaan sabuk keselamatan pada penumpang sudah melebihi dari nilai 2,5. Ini menunjukan bahwa rata-rata responden merasa bahwa penumpang kendaraan harus memakai sabuk keselamatan. pada indikator "Ketaatan saya menggunakan safety belt dipengaruhi lokasi perjalanan " memiliki nilai rataan dibawah 2,5 yang menunjukan bahwa rata-rata responden lebih cendrung menggunakan sabuk keselamatan pada lokasi perjalanan tertentu. pada indikator "Saya selalu menggunakan safety belt ketika menjadi penumpang yang duduk di belakang " memiliki nilai rataan sebesar 1,62 yang berati jauh dibawah nilai rata-rata yaitu 2,5, ini menunjukan bahwa rata-rata responden jarang menggunakan sabuk keselamatan ketika menjadi penumpang yang duduk di belakang, pada indikator perawatan sabuk keselamatan memiliki nilai dibawah 2,5, Ini menunjukan bahwa rata-rata responden jarang melakukan perawatan pada sabuk keselamatan,

\section{KESIMPULAN}

Berdasarkan hasil validasi kemabli survey dan hasil kuesioner analisis tingkat ketaatan penggunaan sabuk keselamatan yang dilakukan secara langsung di Jabodetabek maka dapat diambil kesimpulan sebagai berikut:

1. Berdasarkan hasil survey lapangan terjadi Penurunan persentase penggunaan sabuk keselamatan secara signifikan untuk pengemudi di Jl. Otto Iskandardinata, dan Jl. Raya Bogor

2. Bedasarkan hasil survey lapangan Pria memiliki presentase lebih tinggi dibanding wanita dalam penggunaan sabuk keselamatan.

3. Pada Jl. Halim Perdanakusuma terjadi kenaikan persentase penggunaan sabuk keselamatan oleh pengemudi dan penumpang, hal ini bisa disebabkan karena saat pengambilan data terdapat banyak petugas yang menjaga.

4. Tidak ada perbedaan signifikan penggunaan sabuk keselamatan pada penumpang untuk semua jenis kendaraan pada jalan pinang ranti.

5. Terdapat perbedaan signifikan persentase penggunaan sabuk keselamatan pada pengemudia untuk semua jenis kendaraan pada jalan Raya Taman Mini. Perbedaan signifikan ke arah pengemudi lebih banyak menggunakan sabuk keselamatan.

6. Pada kelompok kepemilikian SIM tidak dijumpai beda signifikan antara kelompok pasangan yang di uji.

7. Terdapat perbedaan signifikan antara ketaatan menggunakan sabuk keselamatan dari faktor internal dengan faktor eksternal. Ini menunjukan bahwa responden sadar harus menggunakan sabuk keselamatan tetapi responden kurang taat untuk penggunaan sabuk keselamatan

8. Responden berjenis kelamin perempuan memiliki nilai rataan lebih tinggi dibanding laki-laki dalam ketaatan menggunakan sabuk keselamatan, ini menunjukan bahwa perempuan lebih taat dalam penggunaan sabuk keselamatan dibanding laki-laki.

9. Responden yang lulusan Sarjana memiliki nilai rataan lebih tinggi dibanding responden lulusan SMA dalam ketaatan penggunaan sabuk keselamatan, ini menunjukan bahwa lulusan Sarjana lebih taat dalam penggunaan sabuk keselmaatan dibanding lulusan SMA.

\section{SARAN}

Saran-saran yang dapat diberikan untuk upaya pengembangan skripsi ini lebih lanjut antara lain:

1. Dikarenakan tidak ada perbedaan hasil antara pengumpulan data secara online maupun langsung dan karena pengambilan data secara online lebih mudah dan cepat, oleh karena itu kedepannya disarankan pengumpulan data lebih baik secara online.

2. Kuesioner harus dikembangkan lagi karena pada hasil pengupulan data masih ada 2 kelompok indikator yang belom reliable untuk ditanyakan.

3. Sebaiknya pemerintah lebih serius dalam sosialiasi penggunaan sabuk keselamatan karena belum tercapai $100 \%$ penggunaan sabuk keselamatan.

4. Pemerintah harus lebih melakukan sosialisasi penggunaan sabuk keselamatan terhadap Angkutan kota karena sudah 14 tahun peraturan berjalan tetapi penggunaan sabuk keselmatan oleh angkutan kota masih $0 \%$.

5. Jika Pemerintah ingin meningkatkan tingkat penggunaan sabuk keselamatan, letakan petugas di setiap ruas jalan untuk mengawas penggunaan sabuk keselamatan. Hal ini dapat dikonfirmasi dari hasil survey pada Jl. Halim Perdanakusuma 


\section{DAFTAR PUSTAKA}

Hagenzieker, M.P. (1992). Drivers' Opinions of Enforcement and Incentive Strategies to Promote Safety Belt Use. Journal of Safety Research vol.23 (1992) pp.199-206.

Johnston, J.J., Hendricks, S.A., Fike, J.M. (1994). Effectiveness of Behavioral Safety Belt Interventions. Accident Analysis \& Prevention Vol. 26 No. 3, 315-323.

Koushki, P.A., Bustan, M.A., Kartam, N. (2001). Impact of Safety Belt Use On Road Accident Injury and Injury Type in Kuwait. Accident Analysis and Prevention Vol. 35 (2003) pp.237-241.

Putranto, L.S (2005). The Effect Road Section Characteristic on Safety Belt Use Rate in Jakarta.

Shinar, D. (1993). Demographic and Socioeconomic Correlates of Safety Belt Use. Accident Analysis \& Prevention Vol. 25 No. 6, 745-755.

Shults, R.A., Elder, R.W., Sleet, D.A., Thompson, R.S., Nichols, J.L. (2004). Primary Enforcement Seat Belt Laws are Effective Even in the Face of Rising Belt Use Rates. Accident Analysis \& Prevention Vol. 36, 491-493.

Streff, F.M., Molnar, L.J. (1991). Use of Automatic Safety Belts in Michigan. Journal of Safety Research Vol. 22, 141-146.

Shults, R.A., Elder, R.W., Sleet, D.A., Thompson, R.S., Nichols, J.L. (2004). Primary Enforcement Seat Belt Laws are Effective Even in the Face of Rising Belt Use Rates. Accident Analysis \& Prevention Vol. 36, 491-493.

Ulmer, R.G., Preusser, C.W., Preusser, D.F., Cosgrove, L.A. Evaluation of California's Safety Belt Law Change from Secondary to Primary Enforcement. Journal of Safety Research Vol. 26 No. 4, 213-220.

Walpole.R.E., Myers.R.H. Probability and Statistics For Engineers and Scientists. Bandung : Penerbit ITB,1986.

Wahidin, Ahmad (2008). Pengaruh Penggunaan Sabuk Keselamatan Terhadap Tingkat Fatalitas Kecelakaan Dan Tingkat Keparahan Kecelakaan. Universitas Dipenogoro. Semarang. 
